\section{Erythroderma after clodronate treatment}

Drs I Pajus, P Lestang, F Lioté, and Prof A Dryll (Hôpital Lariboisiére, 75010 Paris, France) write: The bisphosphonates, including clodronate, are powerful inhibitors of bone resorption. Until now clinical studies of clodronate have shown good tolerability and safety, with no reports of any cutaneous side effects. We report here erythroderma with lesions of the mucous membranes after oral and intravenous clodronate administration.

A 70 year old man was admitted in June 1991 for vertebral pain and hypercalcaemia which led to the diagnosis of stage IIIA multiple myeloma. A single infusion of $300 \mathrm{mg}$ of clodronate was given, and a course of vincristine, melphalan, cyclophosphamide, and prednisolone every four weeks was started. Amiodarone $(200 \mathrm{mg} /$ day) was prescribed for a tachycardia.

Two weeks later he noticed a rash, which lasted three days. On 12 June 1992 he was admitted for the 13th course of chemotherapy. At the same time he received a second infusion of intravenous clodronate $300 \mathrm{mg}$ and was started on oral clodronate $800 \mathrm{mg}$ daily. On 29 June he developed a generalised erythematous macular and papular rash, without pruritus, and a fever of $40^{\circ} \mathrm{C}$. He also had lesions of the buccal and genital mucous membranes and a punctate keratitis. On 1 July his clinical state was unchanged. $\mathrm{He}$ received intramuscular betamethasone and oral $\mathrm{H}_{1}$ antihistamines. The oral clodronate was stopped.

The white blood cell count was normal, without eosinophilia; he had no infection; viral serology gave negative results. A histological examination of the skin showed epidermal changes, with a dermal lymphohistiocytic and eosinophilic infiltration strongly suggestive of toxiderma.

Within a few days the eruption gradually regressed without residual pigmentation. Other drugs were continued without reappearance of the rash.

The delay in the appearance of the rash after the first administration of clodronate, the relapse following its reintroduction, and the regression after the end of clodronate treatment all support clodronate as the cause of the erythroderma, as do the pathological features and the fact that no other drug was introduced.' The cutaneous side effects of bisphosphonates are uncommon. They have been reported with pamidronate ${ }^{23}$ and tiludronate, 4 but only rarely during 10 years' prescription of etidronate. No cutaneous reactions to clodronate have been reported to the French National Centre for Pharmacovigilance or the drug company.'
1 Begaud B, Evreux JC, Jouglard J, Lagier G. Imputabilité des effets inattendus ou toxiques des médicaments. Therapie 1985; 40:111-8.

2 Mautalen CA, Casco CA, Gonzales D, Ghiring helli GR, Massironi C, Fromm GA, Plantalech $L$. Side effects of APD during treatment lech $L$. Side effects of APD during trea

Elliot AT, Murray T, Mackie RM, Hunter JA Severe reaction to diphosphonate: implications for treatment of Paget's disease. BM 1988;297:592-3.

4 Roux C, Listrat V, Villette B, Leibovitch Lessana M, Ethgen D, Pelissier C, Dougado $\mathrm{M}$, Amor B. Long lasting dermatological lesions after tiludronate therapy. Calcif Tissue Int 1992;50:78-80.

5 Mian M, Beghé F, Caprio A, Aloj R, Bertelli A Tolerability and safety of clodronate therapy in bone disease. Int $f$ Clin Pharmacol Res 1991;11:107-14.

\section{Agranulocytosis associated with cephalosporin}

Drs C H Hur and L C Chan (Department of Pathology, University of Hong Kong, Queen Mary Hospital) write: A healthy 15 year old boy was given cefuroxime (Zinacef) $750 \mathrm{mg}$ intravenously every eight hours for fever associated with pneumonia which developed after orthopaedic surgery. As neither fever nor pneumonia improved cefuroxime was discontinued after 17 days and ceftazidime substituted at a dose of $1 \mathrm{~g}$ intravenously twice a day. Twenty four hours later the patient had no fever and a full blood count showed haemoglobin $132 \mathrm{~g} /$, white cell count $6.30 \times 10^{\circ} / 1$ with neutrophils $3.75 \times$ $10^{\circ} / \mathrm{h}$, and platelet count $379 \times 10^{\circ} / 1$. Coagulation and renal and liver function were normal.

On the seventh day of ceftazidime administration fever recurred, and isolated leucopenia (white cell count $\left.1.90 \times 10^{9} / 1\right)$ associated with agranulocytosis (white cell differential $\left(\times 10^{\circ} /\right) 0$ neutrophils, 1.25 lymphocytes, 0.61 monocytes, 0.04 eosinophils) was noted. Ceftazidime was stopped and a bone marrow aspirate the next day showed a normocellular marrow with strikingly reduced myelopoiesis. Bacterial cultures and viral screen were negative. In view of the agranulocytosis, subcutaneous injection of granulocyte macrophage colony stimulating factor 1 phial daily was started. Both total white cell $\left(4.8 \times 10^{9} /\right)$ and neutrophil count $\left(2.2 \times 10^{\circ} / 1\right)$ recovered within 24 hours. Altogether two doses of granulocyte macrophage colony stimulating factor were given, and the white cell counts remained sustained since then.

Transient leucopenia is recognised after cephalosporin administration and is more likely to occur after high doses and prolonged therapy. ${ }^{14}$ In our case we could not determine whether the agranulocytosis was due to ceftazidime or cefuroxime (or both). The prompt recovery may have been due to the cessation of cephalosporin treatment rather than the granulocyte macrophage colony stimulating factor treatment. We suggest that patients should have regular full blood count while receiving cephalosporins.

1 Neftel KA, et al. Inhibition of granulopoiesis in vivo and in vitro by beta-lactam antibiotics. vivo and in vitro by bet

Murphy MF, et al. Cephalosporin-induced immune neutropenia. Br \% Haematol 1985; 59:9-14.

Antibiotic-induced neutropenia. Lancet 1985 ;i: 814.

Anti-infective drug use in relation to the risk of agranulocytosis and aplastic anaemia. A report from the International Agranulocytosis and Aplastic Anaemia Study. Arch Intern Med 1989;149:1036-40.

\section{Cyclosporin induced colitis}

Drs J R C Bowen and S SAHI (BMH Rinteln, BFPO 29, Germany) write: A 40 year old woman presented with a two year history of weight loss, lethargy, and pruritus. Biochemistry tests showed raised alkaline phosphatase concentrations and a high titre of antimitochondrial antibody Liver biopsy confirmed a clinical diagnosis of primary biliary cirrhosis.

Cholestyramine was started for her pruritus, to which cyclosporin was added. Serum concentrations of cyclosporin on a dose of $150 \mathrm{mg}$ daily were $99 \cdot 2 \mathrm{nmol} / 1(124 \mathrm{ng} / \mathrm{ml})$.

Five months later she complained of abdominal pain with increased bowel frequency, loose motions, and mucus per rectum. Investigations showed peripheral blood eosinophilia, but stool microscopy and culture gave negative results, as did upper gastrointestinal endoscopy and a histological examination of the lower duodenun. Colonoscopy, however, showed widespread colitis, confirmed histologically as a "nonspecific colitis."

Cyclosporin was stopped, and all gastrointestinal symptoms resolved within one week. Colonoscopy shortly afterwards showed improved macroscopic and histological appearances.

With the patient's permission she was rechallenged with cyclosporin. This resulted in a recrudescence of her symptoms within four days. Repeat colonoscopy showed a patchy colitis, which was worse than on her previous examination. Histologically the inflammation was comparable in specimens from the second examination, but this might have been due to the necessarily brief rechallenge.

Colitis associated with cyclosporin $A$ has been reported on two previous occasions. ${ }^{12}$ In the first of these, however, drug concentrations were in the toxic range exceeding $640 \mathrm{nmol} / 1(800 \mathrm{ng} / \mathrm{ml})$, and in the second case typical ulcerative colitis started while a patient was receiving cyclosporin and continued despite its withdrawal. To our knowledge this is the first reported case of a reversible cyclosporin induced colitis occurring

in a patient with cyclosporin concentrations in the therapeutic range.

1 Innes $A$, Rowe $P$, Foster $M$, Steiger $M$, Morgan A. Cyclosporin toxicity and colitis (letter). Lancet 1988;2:957.

2 Divisions of Nephrology and Gastroenterology, Free University of Berlin. Onset of ulcerative colitis in a cyclosporin treated patien. Lancet 1991;338:389.

\title{
Transcutaneous overdose of
} terbutaline

Drs G J Ingrams (Kidderminster General Hospital, Kidderminster DY11 6RD and F B MORGAN (Aylmer Lodge Surgery, Kidderminster) write: A 15 year old mildly asthmatic boy was admitted with tachycardia (rate 130 beats $/ \mathrm{min}$ ), a loud systolic murmur at his left sternal edge, and tremor. Feeling slight tightness of his chest after playing football, he had inhaled two puffs $(500 \mu \mathrm{g})$ of terbutaline. $\mathrm{He}$ then discovered that spraying the aerosol on to a patch of itching tinea crutis in his groin produced cooling relief and administered at least eight puffs. Ten minutes later he developed fast, regular palpitations and an uncomfortable feeling in his chest and therefore inhaled a further two puffs.

Investigations showed hypokalaemia $(2.7 \mathrm{mmol} / \mathrm{l})$, hyperglycaemia $(14.8 \mathrm{mmol} / \mathrm{l})$, normal arterial blood gas values, and sinus tachycardia. A subsequent echocardiogram was normal. His signs and symptoms were consistent with terbutaline overdose and settled over 24 hours without specific treatment. The total inhaled dose $(1 \mathrm{mg})$ was insufficient to cause such a clinical picture, but the total dose sprayed on to the skin $(2 \mathrm{mg})$ was four times greater than the maximum dose for subcutaneous injection $(500 \mu \mathrm{g})$.

Although transcutaneous absorption has not been documented for $\beta_{2}$ agonists, the absorption of terbutaline is increased across damaged tracheal epithelium in vitro.' Overdose of $\beta_{2}$ agonists is associated with hypokalaemia, ${ }^{2}$ which can cause sudden death. ${ }^{34}$ Transcutaneous absorption should be considered, particularly when nebulising atopic 